\title{
Export and Innovation Activities in the German Service Sector Empirical Evidence at the Firm Level
}

\author{
by \\ Günther Ebling \& Norbert Janz \\ ebling@zew.de janz@zew.de \\ Centre for European Economic Research (ZEW)
}

October 28, 1999

\begin{abstract}
In this paper we analyse the relationship between export and innovation activities of German service sector companies using data from the 1997 wave of the Mannheim Innovation Panel in the Service Sector. There is a lot of support for the Schumpeterian hypothesis of export activities being mainly driven by innovation activities. Factor endowment theories are only partially supported. While human capital significantly improves export performance, labour costs hamper it only in selected branches. Moreover, allowing for simultaneity we find that export activities do not enforce innovation activities.
\end{abstract}

Keywords: exports, innovation, service sector, firm behaviour, applied microeconometrics

JEL Classification: F14, O31, C53, L80

corresponding author: Norbert Janz

Centre for European Economic Research (ZEW)

Department of Industrial Economics and International Management

P.O. Box 1034 43, D-68034 Mannheim, Germany 


\section{Introduction}

In most OECD countries the structure of the economy has changed towards the service sector. Much more people are now employed in the service sector than in manufacturing. But it is only recently that the focus of innovation research has been directed to service firms (see Miles, 1994). The service sector has long been regarded as depending on the manufacturing sector, not innovating itself. While the service sector has gained attention in empirical innovation research it is still neglected in empirical research on export activities. Services are still regarded as a good example for non-tradeable goods. However, due to efforts in deregulating and big advances in communications technology, services have actually become tradeable to a considerable extent. About 20\% of all German service sector firms report export activities (see Ebling et al., 1999).

Innovation activities seem to play an important role in explaining differences in performance and export activities of firms. These are the main implications of recent economic theory on international trade flows and also the results of most studies on the relationship between export and innovation activities at firm level in the manufacturing sector (see e.g. Brouwer and Kleinknecht, 1993, and Wakelin, 1998). But still, the evidence is not clear cut (see e.g. Schlegelmilch and Crook, 1988). For service sector firms no empirical evidence is available at all. By testing whether theoretical results for tradeable goods and empirical evidence for manufacturing firms may be transferred to service firms this empirical gap is partly closed in this paper.

We analyse the relationship between export and innovation activities in German business related service industries, using data from the 1997 wave of the Mannheim Innovation Panel in the Service Sector (MIP-S). The paper continues with the following outline: Section 2 summarizes the main theoretical results on factors explaining trade flows and gives an overview of empirical evidence on export activities available at sector and firm level. The empirical model which results from adopting the empirical approach of recent studies for manufacturing firms and the chosen measures for relevant variables are explained in section 3. In contrast to most studies we take into account that innovation activities may depend on export activities. Section 4 gives information on the data set and some descriptive statistics for the firms considered. 
Econometric evidence is presented in section 5. We use single as well as simultaneous probit estimates to analyse the interdependencies between export and innovation activities and other firm characteristics. Section 6 concludes.

\section{Determinants of Export Activities}

Up to now, there is no unified theory of an exporting firm. In the empirical literature on export behaviour, relevant variables are selected in a rather adhoc manner. Only few authors use mathematical formulations of the firm's decision problem. ${ }^{1}$

Theoretical results on factors explaining export activities are available from economic theory of international trade (see Krugman, 1995; and Gandolfo, 1998). The traditional neoclassical view of international trade explains trade flows with differences in factor endowments in the context of the HeckscherOhlin model. Resulting factor proportions or neo-factor proportions hypotheses would suggest that it is relative endowment of labour and capital, and in more recent approaches human capital or knowledge capital, which drives export flows.

Since the challenging paper of Posner (1961), Schumpeterian views on international trade have been gaining more and more attention. According to this neo-technology or neo-Ricardian view, as it is sometimes called, in a dynamic context, innovation or differences in technology are the main reason especially for intra-industry trade flows. In industrialized countries, technological gaps are induced by innovation activities, especially product innovations. Resulting temporary monopolies give incentives for imitation which lead to vanishing technological gaps. In consequence, according to the Schumpeterian view, innovation activities should be the main factor driving export flows in advanced economies.

Similar results are deduced from the product life-cycle hypothesis first introduced by Vernon (1966). In economies with a high level of income, products

\footnotetext{
${ }^{1}$ Entorf, Krader, and Pohlmeier (1988) use an extension of the competitive fringe model to analyze the interdependence between innovation, export activities and labour demand. But their main focus is on resulting effects on labour demand.
} 
are developed and produced primarily for the domestic markets. If the domestic market is matured, firms will start to export until the production becomes routinized and the technology is transferred to foreign countries with lower production costs. Again, exports are strongly linked to innovation activities. ${ }^{2}$ Starting with Gruber et al. (1967), a number of empirical studies tried to establish the link between exports and innovation in the manufacturing sector at the level of industries. Exports are measured as ratio of exports to total sales (Gruber et al., 1967), as excess of exports over imports to total sales (again Gruber et al., 1967), as ratio of exports to imports (Soete, 1981) or as share of exports in total OECD exports (again Soete, 1981). Some authors use more complex measures based on the concept of revealed comparative advantage developed by Balassa (1965) considering sectoral and regional structures of exports and imports (e.g. Wolter, 1977; Soete, 1981; and more recently Dosi et al., 1990; or Wolff, 1997).

Various measures for firm innovation activities have been used. Earlier studies use quite narrow input measures of innovation processes like $R \& D$ expenditures in relation to total sales or ratio of $R \& D$ employees to total employment (Gruber et al., 1967; and Wolter, 1977). Since export performance is more likely to be affected by the output of innovation processes, attempts have been made to find appropriate output measures. Soete $(1981,1987)$ uses the share of patent applications in total OECD patents. ${ }^{3}$ Most of these studies find a positive correlation between the chosen measure of innovation and export activities.

First empirical evidence at firm level for manufacturing companies has been given by Hirsch and Bijaoui (1985) and Schlegelmilch and Crook (1988). Both studies approximate innovations by $R \& D$, but lead to contradicting results. Regressing changes in exports on percentage of $R \& D$ employees using a sample of R\&D-performing firms in the United States, Hirsch and Bijauoi (1985) find a positive impact of innovations on exports. Schlegelmilch and Crook (1988)

\footnotetext{
${ }^{2}$ Formal models linking trade and innovation using the ideas of Posner (1961) and Vernon (1966) have been introduced by Nelson and Norman (1977) and Krugman (1979).

${ }^{3}$ Since only major inventions are patented and not all patented innovations are marketable, the number of patent applications is generally considered to be a poor measure of innovation success (see Griliches, 1990).
} 
do not. The results of Kumar and Siddarthan (1994) are mixed, depending on the industry. Findings of Brouwer and Kleinknecht (1993), measuring exports as share of exports in sales and innovation as product-related $R \& D$ man years in total labour force, support the results of Hirsch and Bijaoui (1985).

But, R\&D does not capture all aspects pertinent to innovation activities, like e.g. marketing activities for the introduction of new products (see OECD/Eurostat, 1997). In a study on export activities of manufacturing firms in the German state Lower Saxony, Wagner (1996) uses a dummy-variable for the introduction of new products as measure for innovation activities. He finds a positive impact of innovation on exports. Wakelin $(1997,1998)$ uses a dummy-variable indicating an innovating firm and the number of innovations in the past as innovation indicators. For a sample of UK manufacturing firms, she finds a positive impact on the probability to be an exporting firm as well as on the propensity to export.

In recent literature on endogenous economic growth (Romer, 1986, and especially Grossman and Helpman, 1991) it is argued the causality may run from trade to technical change, i.e. from export to innovation activities, as well as vice versa. Opening up of foreign markets will enlarge profits stemming from innovation activities and thus enforce innovation. The possibility of endogenous innovations has been ignored in the empirical literature on firm export behaviour, with the exception of Entorf, Krader, and Pohlmeier (1988). They use a simultaneous equation framework to investigate the empirical relationship between exports and innovation, and labour demand. Measuring innovation activities as dummy variable indicating an innovative firm and by share of sales with products in the beginning of the product cycle with German data from the ifo business survey, they find a positive impact of innovation on export behaviour, but also of export activities on innovation behaviour.

However, all of the existing studies at firm level focus on manufacturing firms. For service firms, the interdependence between innovation and export activities has not been empirically investigated. Only recently has the service sector been recognized as an innovating sector (see Miles, 1994). Services are still regarded as a good example for non-tradeable goods. But due to efforts in deregulating and big advances in communications technology, services have actually become tradeable to a considerable extent. In Germany, about $20 \%$ of all service sector 
firms report export activities (see Ebling et al., 1999).

\section{Empirical Model}

To test whether theoretical results from trade theory and empirical evidence for manufacturing firms may be transferred to service firms, we adopt the approach of recent firm level studies in the manufacturing sector (Kumar and Siddhartan, 1994; and Wakelin, 1998). In contrast to most of these studies we take into account that innovation activities may depend on export activities.

We define the relationship, which is to be empirically analysed, as

$$
\operatorname{Exp}_{i j}=\mathrm{f}\left(\text { Inno }_{i j}, Z_{i j}^{E x p}, S_{j}^{E x p}, E^{E x p}\right)
$$

The measure of exports $\operatorname{Exp}_{i j}$ of firm $i\left(i=1, \ldots, N_{j}\right)$ in sector $j(j=1, \ldots, M)$ is a function of a measure for innovative activities $\operatorname{Inno}_{i j}$, a vector for other characteristics of the firm $Z_{i j}^{E x p}$ reflecting especially factor endowment variables, a vector of sector characteristics $S_{j}^{E x p}$ and a vector for characteristics of the economy $E^{E x p}$. The vectors $Z_{i j}^{E x p}, S_{j}$ and $E$ consist of variables which are likely to affect the firm's export activities, variables predicted by traditional and modern theory of international trade and export behaviour.

Sector-level studies on effects of innovation on international trade use several measures of export activity. At firm-level the ratio of exports to sales $\operatorname{Exp}_{i j}=\frac{\text { exports }_{i j}}{(\text { total sales })_{i j}}$ is generally regarded to be an appropriate measure of export performance $^{4}$ (see Wagner, 1996, and Wakelin, 1998). In our study we use a dummy variable characterizing an exporting firm as observable measure of export activity.

As stated in section 2, various measures for firm innovation activities $I_{i j}$ have been used in relevant studies to test empirical implications of economic theory. However, most of the existing measures have fundamental drawbacks with regard to service firms: Only few service firms are performing R\&D, patenting is of minor importance in the service sector, share of sales with new products is

\footnotetext{
${ }^{4}$ In contrast to more recent literature, Hirsch and Bijaoui (1985) use rate of change in exports.
} 
difficult to measure in mostly individual services, and product innovations can hardly be distinguished from process innovations, because there is no clearly defined production process in most of the service sector industries (see Licht et al., 1997). Therefore, we use the ratio of innovation expenditures to sales

$$
\operatorname{Inno}_{i j}=\frac{(\text { innovation expenditures })_{i j}}{(\text { total sales })_{i j}}
$$

as a broad measure which is able to capture all aspects of innovation activities in service firms.

Besides innovation activities, economic theory suggests other firm characteristics to affect export activity. Traditional neoclassical trade theory would suggest that it is relative endowment of labor, capital and knowledge capital which drives export flows. Relative factor endowments are usually measured by factor intensities or relative factor prices (see Wolter, 1977, and Soete, 1981).

Since information on factor intensities is not available for the firms considered, we have to look for other variables which might capture differences in relative factor endowments. We use unit labor costs

$$
\text { Unit } L C_{i j}=\frac{(\text { total labor costs })_{i j}}{(\text { total sales })_{i j}}
$$

as a measure for relative endowment with labor. The neoclassical extension of production factors to knowledge or human capital can be captured by measures for skill structures of employees (Oulton, 1996 and Wagner, 1996):

$$
\begin{aligned}
U n i v_{i j} & =\frac{(\text { employees with univ. or college degree })_{i j}}{(\text { number of employees })_{i j}} \\
S k i l l_{i j} & =\frac{(\text { skilled employees without univ./college degree })_{i j}}{(\text { number of employees })_{i j}}
\end{aligned}
$$

Since skill structure considers only formal and not necessarily real levels of qualification, it may turn out to be an inadequate measure for knowledge capital. Additionally, average wages in opposition to unit labor costs have been used in some studies (e.g. Wakelin, 1998) as a measure for human capital.

$$
\text { Wage }_{i j}=\frac{(\text { total labor costs })_{i j}}{(\text { number of employees })_{i j}}
$$


Since Germany is generally regarded to be poorly endowed with labor and richly endowed with knowledge capital, we expect unit labor costs to have a negative impact and skill structure or average wages to have a positive impact on exports.

Opening up export markets is usually associated with relatively high fixed costs. Financial means of covering the burden of fixed costs is related to firm size. Therefore, firm size measured by total number of employees is regarded to be an important factor in explaining export activities (e.g. Kumar and Siddharthan, 1994). To allow for non-linearities in the relationship between exports and firm size, we add the logarithm of firm size and the squared logarithm of firm size

$$
\begin{aligned}
& \text { Size }_{i j}=(\text { logarithm of the number of employees })_{i j} \\
& \text { Size2 }_{i j}=(\text { logarithm of the number of employees })_{i j}^{2}
\end{aligned}
$$

to the list of possible explanatory variables. Generally, an inverse U-shaped relationship between exports and firm size is expected (Kumar and Siddharthan, 1994).

As stressed by Brouwer and Kleinknecht (1993), opportunities of opening up new markets may depend on the organizational structure of the company. Given size, firms which are part of a conglomerate may have easier access to financial capital necessary for investments. Therefore, the dummy

$$
\text { Cong }_{i j}=(\text { dummy for being part of a conglomerate })_{i j}
$$

is a potential explanatory variable.

To control for spatial effects resulting from the location of firms close to the border of another country, we add a dummy variable covering the district or county (Kreis) where the head office is located.

$$
\text { Border }_{i j}=(\text { dummy for border districts })_{i j}
$$

Additionally, another special regional variable is added to allow for expected differences between firms located in the eastern part of Germany (Neue Bundesländer) and companies in the former territory of Germany (Alte Bundesländer):

$$
\text { East }_{i j}=(\text { dummy for Neue Bundesländer })_{i j}
$$


The firms' export activities are additionally influenced by sector and economy characteristics. Prior studies have considered different variables at sector level. Brouwer and Kleinknecht (1993) use the seller concentration ratio to control for competitive aspects on domestic markets, arguing that firms in highly competitive markets are more likely to engage in exports. Wakelin (1998) stresses the importance of knowledge spillovers. Firms acting in an innovative market environment might be more engaged in exports. Since we use a single cross section of firms, all possibly relevant sector characteristics are captured by a set of industry dummies in the empirical part of the paper. Moreover, economy characteristics like exchange rates are negligible in cross sections and captured by the constant term.

Following Entorf, Krader and Pohlmeier (1988) we use a simultaneous equation framework. For this reason, we specify an equation explaining innovation activities.

$$
\text { Inno }_{i j}=\mathrm{g}\left(\operatorname{Exp}_{i j}, Z_{i j}^{\text {Inno }}, S_{j}^{\text {Inno }}, E^{\text {Inno }}\right)
$$

The chosen measure of innovation activities $\operatorname{Inno}_{i j}$ is a function of export activities $E x p_{i j}$, a vector for other firm characteristics $Z_{i j}^{I n n o}$, a vector of sector characteristics $S_{j}^{I n n o}$ and a vector for characteristics of the economy $E^{\text {Inno. }}$. Sector and economy characteristics are again captured by sector dummies and the constant term.

The vectors $Z_{i j}^{\text {Inno }}$ consist of firm specific variables which affect innovation activities. We use a common specification (e.g. Entorf, Krader, and Pohlmeier, 1988) with some modifications for service sectors (see Licht and Moch, 1997). Most variables introduced for the analysis of export activities may also be used in the innovation equation. As stated above, the skill variables $U n i v_{i j}$

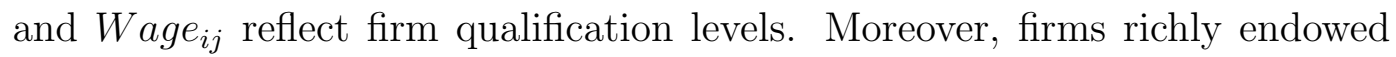
with human capital are supposed to be more successful in introducing a new innovation to the market; in this context then, a positive sign is expected for the skill variable.

Firms which decide to introduce new products to the market or to implement new processes might be faced with high fixed costs. Just as in the case of 
exports, larger firms should experience economies of scale. We therefore expect size variables $S_{i z e_{i j}}$ and $S_{i z e} \mathscr{Q}_{i j}$ to have an inverse U-shaped effect on innovation activities.

Several other variables are regularly used in relevant literature to explain innovation activities of a firm. The substantial impact of information technology has been thoroughly discussed by Licht and Moch (1997). They show that nearly all innovative firms view information technologies as key elements for innovative activities:

$$
I n v I_{i j}=\frac{(\text { total investment in IT })_{i j}}{(\text { total sales })_{i j}} .
$$

Besides investment in physical capital, the company's investment in human capital is of interest to explain innovative behaviour especially in services. Total expenditures in training per employee

$$
\text { Training }_{i j}=\frac{(\text { total expenditure on training })_{i j}}{(\text { number of employees })_{i j}}
$$

is a reasonable approximation to describe human capital investments of the firm.

\section{Data Set and Descriptive Statistics}

We use data from the 1997 Mannheim Innovation Panel in the Service Sector (MIP-S, see Ebling et al., 1999) to test the empirical model. After rejecting observations with item non-response in variables of interest, we are left with a sample of $N=\sum_{j=1}^{M} N_{j}=1,010$ firms out of $M=7$ service sector industries. We concentrate on business oriented services, i.e. transportation, data processing and telecommunications, technical consultancies and engineering, housing services, consulting and advertising, industrial cleaning and waste disposal, and other more business oriented services. Wholesale, retail, banking, insurance, and financial services are not considered.

The service sector has always been seen as producing non-tradeable goods. In our sample of $N=1010$ firms a number of 193 (about 20\%) reported 
exporting of services in the year 1996. Moreover, 491 firms (almost 50\%) reported innovation activities. Table 1 gives a brief overview of the number of exporting and innovative firms according to service industries.

\section{Table 1 about here.}

The share of exporting firms is relatively high especially in data processing and telecommunications, but also in technological consultancies and engineering services. These two branches are also the ones reported to be the most innovative.

Some descriptive statistics of variables considered for the two groups of exporting and non-exporting firms on the one hand and innovative and noninnovative firms on the other hand are summarized in table 2. We report mean and standard deviation for quantitative variables and the mean for qualitative variables, equal to the share of firms with the realization of value 1 for the binary variable considered.

\section{Table 2 about here.}

As can be seen in table 2, exporting firms are more often innovators. The same may be said of total expenditure for innovations. In exporting firms, average expenditure for innovations is larger than in non-exporting firms. Exporting firms pay higher average wages without higher labor unit costs. They are larger measured by number of employees, a fact well known in the manufacturing industry (e.g. Kumar and Siddharthan, 1994). Moreover, exporting firms are less often located in East Germany and more often situated at the border to another country.

Of course, large standard deviations of most of the different variables indicate a considerably high variation not only between groups of exporting and nonexporting firms but also within these groups.

Similar arguments hold for innovating firms. More often they are exporters. In addition, pertaining to number of employees they are larger, as expected. They are more often located in West Germany and more often part of a conglomerate. 
These stylized facts give reason to suppose that innovative firms and firms with higher level of knowledge capital have a higher probability of exporting. This will be explored in more detail in the subsequent section of econometric results.

\section{$5 \quad$ Econometric Results}

In this chapter, we present first econometric evidence on export behaviour of German service firms with special regard to the effects of innovation activities on export performance. We use a two step approach. First, we use a simple probit model to analyse export activities taking innovation activities as given. Second, we generalize and allow for endogeneity of innovation activities using a simultaneous probit model.

We start with a Probit model (compare Maddala, 1983) of the decision to export. The export equation is given by the latent model

$$
\operatorname{Exp}_{i j}^{*}=\alpha \operatorname{Inno}_{i j}+\beta^{\prime} Z_{i j}^{E x p}+u_{i j}
$$

$I_{n n o}{ }_{i j}$ is the measure for innovation activities and $Z_{i j}^{E x p}$ the column vector of firm characteristics including industry dummies and a constant term. $\alpha$ and the column vector $\beta$ define a set of parameters to be estimated. The error term $u_{i j}$ is assumed to be iid $\mathcal{N}\left(0, \sigma_{u}\right)$. The export measure $E x p_{i j}^{*}$ cannot be observed completely. The observed model is given by the binary choice

$$
\operatorname{Exp}_{i j}= \begin{cases}1 & \text { if } \quad E x p_{i j}^{*}>0 \\ 0 & \text { if } \quad E x p_{i j}^{*} \leq 0\end{cases}
$$

formally defining an exporter and a non-exporter. Results of the MaximumLikelihood estimations are summarized in table 3. We use two different measures for innovation activities: the ratio of innovation expenditures to total sales in the left part of table 3 and the state of being an innovative firm in the right part.

Table 3 about here. 
The empirical results are very robust concerning the chosen measure for innovation activities. Innovation has a clear positive impact on exports. These results support the Schumpeterian hypothesis for the service sector.

Measures for the neoclassical factor endowment variables only partially yield the signs expected. The coefficient of unit labour costs is significantly negative only for the branches of transportation, technical consultancy and engineering, and the other unspecified services, but insignificant for all other sectors. The labour costs variable would be insignificant if we did not allow the coefficients to differ between service sectors. The coefficient of average wages is significantly positive. However, skill structure is insignificant even if average wages are omitted from the equation. This gives reason to assume that the formal level of qualification does not coincide with the qualification of employees needed to succeed on foreign markets. We examine this assumption more closely in the second stage of our analysis.

The dummy describing if the firm is located at a border to other countries is significantly positive. ${ }^{5}$ Being close to the border, firms know better about possible differences between customers in the domestic and the foreign market. As borders in the European Union have opened up more and more, frontiers have become less significant, especially for firms located close to a border. The relevant market consists mainly of neighbouring regions, including adjacent counties across the borders. The short distance reduces possible transportation costs for exporting firms.

The dummy for East Germany is significantly negative, indicating that firms in the Neue Bundesländer are still less likely to export than firms in the Alte Bundesländer. These structural differences were expected. Firms in the eastern part of Germany still have problems to keep up with firms from the western part.

All other variables are not significant: Surprisingly, we do not find clear evidence for size effects. If we test for the significance of the coefficients of both size variables simultaneously they are significant only at a $10 \%$ level and only in the first probit equation (see table 5). The dummy for being part of a con-

\footnotetext{
${ }^{5}$ The sample only includes firms which are located at the border in the western part of Germany.
} 
glomerate is insignificant as well, although we supposed that the infrastructure of a conglomerate which was at disposal of these firms facilitated export. ${ }^{6}$ To summarize, hard economic factors, as predicted by Schumpeterian and neoclassical arguments, clearly outperform softer business arguments.

To allow for endogeneity of innovation behaviour in the second step of our analysis, we consider the following simultaneous probit model (Mallar, 1977) of export and innovation activities. The export and innovation equations are given by the latent simultaneous equation model

$$
\begin{aligned}
E_{x p}^{*} & =\alpha I n n o_{i j}^{*}+\beta^{\prime} Z_{i j}^{E x p}+u_{i j} \\
I_{n n o}^{*} & =\gamma \operatorname{Exp}_{i j}^{*}+\delta^{\prime} Z_{i j}^{I n n o}+v_{i j}
\end{aligned}
$$

In addition to equation (3), Inno ${ }_{i j}^{*}$ defines the latent measure of innovation activities, $Z_{i j}^{\text {Inno }}$ the column vector of firm characteristics including industry dummies and a constant. $\gamma$ and the column vector $\delta$ are parameters of the innovation equation. The error term $v_{i j}$ is assumed to be iid $\mathcal{N}\left(0, \sigma_{v}\right)$ and possibly correlated with $u_{i j}$.

The observed model is given by the binary variables

$$
\begin{aligned}
& \operatorname{Exp}_{i j}=\left\{\begin{array}{lll}
1 & \text { if } \quad \operatorname{Exp}_{i j}^{*}>0 \\
0 & \text { if } \quad \operatorname{Exp}_{i j}^{*} \leq 0
\end{array}\right. \\
& \text { Inno }_{i j}=\left\{\begin{array}{lll}
1 & \text { if } & \text { Inno }_{i j}^{*}>0 \\
0 & \text { if } \quad \text { Inno }_{i j}^{*} \leq 0
\end{array}\right.
\end{aligned}
$$

We use the two step procedure of Mallar (1977) starting with a probit estimation of the reduced form which can be estimated consistently. The predictions of the endogenous indices can then be used for a simple probit maximum likelihood estimation of both equations.

With this, the consistently estimable structural relations are

$$
\begin{aligned}
\operatorname{Exp}_{i j}^{* *} & =\frac{\operatorname{Exp}_{i j}^{*}}{\sigma_{u}}=\frac{\alpha \sigma_{v}}{\sigma_{u}} \operatorname{Inno}_{i j}^{* *}+\frac{\beta}{\sigma_{u}} Z_{i j}^{E x p}+\frac{u_{i j}}{\sigma_{u}} \\
\text { Inno }_{i j}^{* *} & =\frac{I_{n} o_{i j}^{*}}{\sigma_{v}}=\frac{\gamma \sigma_{u}}{\sigma_{v}} \operatorname{Exp}_{i j}^{* *}+\frac{\delta}{\sigma_{v}} Z_{i j}^{I n n o}+\frac{v_{i j}}{\sigma_{v}}
\end{aligned}
$$

\footnotetext{
${ }^{6}$ The test results do not change, if we allow for differing effects of conglomerates with head office in Germany and abroad.
} 
For the estimation of the standard errors we use the correction of the covariance matrix proposed by Madalla (1983). Results of the two-step MaximumLikelihood estimations are shown in table 4.

\section{Table 4 about here.}

Outcomes of the single probit estimations are supported by results of simultaneous probit estimations. Innovation still has a distinctly positive impact on exports. Firms with new or improved services are able to offer resistance to the stronger competition on foreign markets much better than non-innovative service providers. Regarding the effect of innovation activities, service companies are therefore not different from firms in manufacturing (see Brouwer and Kleinknecht, 1993; and Wakelin, 1998). The measure of exports on the other hand is not significant in the innovation equation. Whereas innovation activities increase the export probability of firms in the service sector, the opposite effect can not be validated by our data. Potentially enlarged profits induced by export activities do not enforce innovation.

The estimates of the other coefficients of the export equation are not very different from the single probit estimation above. Again, the effects of unit labour costs are only significantly negative in selected branches: transportation, technical consultancy and engineering, and other unspecified services, whereas the average wage reflecting human capital is significantly positive. Again, skill structure is insignificant even if average wages are omitted from the equation. For this reason, corresponding variables were omitted from the set of variables explaining exports.

On the other hand, skill structure proves to be important in explaining innovation activities. This gives reason to assume that the type of qualification needed for firms to succeed in exports on the one hand and to carry out innovation activities on the other hand is different. Firms which engage in innovation projects need employees with qualification of some kinds which can be captured by formal skill variables used in the innovation equation: The higher the proportion of employees with university degree out of the total number of employees, the higher is the probability of innovation activities. However, the skills of employees needed to succeed in the export business do obviously 
not necessarily coincide with this formal level of qualification. Qualification of employees needed to succeed on foreign markets, acquired e.g. through learning on the job, might rather be reflected in the level of average wages. This, in turn, leads to the conclusion that high wages, often mentioned by German firms as a main disadvantage over firms from other countries, are not necessarily a hampering factor for the success of a firm as long as they reflect the human capital of the firms' employees.

The significance and sign of the remaining variables are the same as in the simple probit equation: Spatial effects are reflected in the significantly positive coefficient of the border dummy, and firms in the Neue Bundesländer are less likely to export. Size variables are now insignificant even at the $10 \%$ level.

\section{Table 5 about here.}

The correlation between size and probability to export as seen in the descriptive statistics in table (2) can be uncovered as an indirect effect: Large firms are more likely to innovate, innovative firms in turn are more likely to export. The effect that larger firms are more likely to export since they can bear necessary initial investments more easily can not be validated with our data. As suspected, besides skill structure and firm size, investment in IT has a considerable impact on the probability to innovate.

\section{Summary and Conclusion}

In this paper, we have investigated the relationship between export and innovation activities in the German service sector allowing for endogeneity of innovation activities. We econometrically tested whether results from trade theory and empirical evidence for manufacturing firms may be transferred to service firms.

Most of the results coincide with results from recent firm level studies in the manufacturing sector (e.g. Brouwer and Kleinknecht, 1993 and Wakelin, 1998). We find strong support for the Schumpeterian hypothesis that export activities in the service sector are strongly influenced by innovation activities. Similarly, 
we find that knowledge capital, if measured by the level of average wages, has a clear positive impact on innovation. However, we find a significantly negative impact of unit labor costs on exports only for selected service sector branches. Moreover, we do not find evidence for firm size directly affecting exports. Firm size has an indirect impact on exports via innovation activities. Additionally, we do not find a feedback relationship between exports and innovation. Possibly enlarged profits induced by export activities do not enforce innovation in the service sector.

\section{Acknowledgments:}

We would like to thank Herbert Buscher, Dirk Czarnitzki, and Dietmar Harhoff for helpful comments, Thorsten Doherr and Hiltrud Niggemann for support in preparing the data base as well as Alexandra Scheu and Semka Thorvaldsen for proof reading. Previous drafts of this paper have been presented at the EARIE 1998 in Copenhagen, the Annual Meeting of the Verein für Socialpolitik 1998 in Rostock and the TSER workshop on innovation survey data in Paris 1998.

\section{References}

Balassa, B. (1965), Trade Liberalization and Revealed Comparative Advantage, Manchester School of Economic and Social Studies 33, 99-123.

Brouwer, E. and A. Kleinknecht (1993), Technology and a Firm's Export Intensity: The Need for Adequate Innovation Measurement, Konjunkturpolitik 39, 315-325.

Dosi, G., K. Pavitt and L. Soete (1990), The Economics of Technical Change and International Trade, London.

Ebling, G., C. Hipp, N. Janz, G. Licht and H. Niggemann (1999), Innovationsaktivitäten im Dienstleistungssektor: Ergebnisse der Innovationserhebung 1997, in: N. Janz and G. Licht (eds.), Innovationsaktivitäten in der deutschen Wirtschaft, Analyse der Mannheimer Innovationspanels im Verarbeitenden Gewerbe und im Dienstleistungssektor, Schriftenreihe des ZEW, Bd. 41, Baden-Baden, 99-222. 
Entorf, H., W. Krader and W. Pohlmeier (1988), Entscheidungen über Innovation, Beschäftigung und Außenhandel: Empirische Ergebnisse eines simultanen Probitansatzes, in: H. Kräger (Hrsg.), Empirische Wirtschaftsforschung, Heinz König zum 60. Geburtstag, Frankfurt am Main, 27-47.

Gandolfo, G. (1998), International Trade Theory and Policy, Berlin.

Griliches, Z. (1990), Patent Statistics as Economic Indicators: A Survey, Journal of Economic Literature 28, 1661-1707.

Grossman, G. and E. Helpman (1991), Innovation and Growth in the Global Economy, Cambridge.

Gruber, W.H., D. Mehta, and R. Vernon (1967), The R\&D Factor in International Trade and Investment of U.S. Industries, Journal of Political Economy 75, 20-37.

Hirsch, S. and I. Bijaoui (1985), R\&D Intensity and Export Performance: A Micro View, Weltwirtschaftliches Archiv 121: 238-251.

Krugman, P. (1979), A Model of Innovation, Technology Transfer, and the World Distribution of Income, Journal of Political Economy 87, 253266.

Krugman, P. (1995), Technological Change and International Trade, in: Stoneman, P. (ed.), Handbook of the Economics of Innovation and Technological Change, Oxford, 342-365.

Kumar, N. and N.S. Siddharthan (1994), Technology, Firm Size and Export Behaviour in Developing Countries: The Case of Indian Enterprises, Journal of Development Studies 31, 289-309.

Licht, G., C. Hipp, M. Kukuk and G. Münt (1997), Innovationen im Dienstleistungssektor, Empirischer Befund und wirtschaftspolitische Konsequenzen, Schriftenreihe des ZEW, Bd. 24, Baden-Baden.

Licht, G. and D. Moch (1997), Innovation and Information Technology in Services, Discussion Paper 97-20, Zentrum für Europäische Wirtschaftsforschung, Mannheim. 
Maddala, G.S. (1983), Qualitative and Limited Dependent Variables in Econometrics, Cambridge.

Mallar, C.D. (1977), The Estimation of Simultaneous Equation Probability Models, Econometrica 45, 1717-1727.

Miles, I. (1994), Innovation in Services, in: M. Dodgson and R. Rothwell (eds.), Handbook of Industrial Innovation, Cheltenham, 243-256.

Nelson, R. and V. Norman (1977), Technological Change and Factor Mix over the Product Cycle: A Model of Dynamic Comparative Advantage, Journal of Development Economics 4, 3-24.

OECD/Eurostat (1997), Oslo Manual, Proposed Guidelines for Collecting and Interpreting Technological Innovation Data, Organisation for Economic Co-Operation and Development, Statistical Office of the European Communities, Paris.

Oulton, N. (1996), Workforce Skills and Export Competitiveness, in: A. L. Booth and D. J. Snower (eds.), Acquiring Skills: Market Failure, their Symptoms and Policy Responses, Cambridge, 201-230.

Posner, M. V. (1961), International Trade and Technical Change, Oxford Economic Papers 13, 323-341.

Romer, P. (1986), Increasing Returns and Long-Run Growth, Journal of Political Economy, 94, 1002-1037.

Schlegelmilch, B.B. and J.N. Crook (1988), Firm-Level Determinants of Export Intensity, Managerial and Decision Economics 9, 291-300.

Soete, L. (1981), A General Test of Technological Gap Trade Theory, Weltwirtschaftliches Archiv 117, 638-659.

Soete, L. (1987), The Impact of Technological Innovation on International Trade Patterns: The Evidence Reconsidered, Research Policy 16, 101130.

Vernon, R. (1966), International Investment and International Trade in the Product Cycle, Quarterly Journal of Economics 80, 190-207. 
Wagner, J. (1996), Export Performance, Human Capital, and Product Innovation in Germany: A Micro View, Jahrbuch für Wirtschaftswissenschaften $47,40-45$.

Wakelin, K. (1997), Trade and Innovation, Theory and Evidence, Cheltenham.

Wakelin, K. (1998), Innovation and export behaviour at the firm level, Research Policy 26, 829-841.

Wolff, E.N. (1997), Productivity Growth and Shifting Comparative Advantage on the Industry Level, in: J. Fagerberg, J., J. Hansson, L. Lundberg and A. Melchior (eds.), Technology and International Trade, Cheltenham, 1-19.

Wolter, F. (1977), Factor Proportions, Technology and West German Industry's International Trade Patterns, Weltwirtschaftliches Archiv 113, 250267. 
Table 1: Sample by Service Industries

\begin{tabular}{|ll||c|c|c|}
\hline & & \multirow{2}{*}{ Total } & \multicolumn{2}{c|}{ thereof } \\
& & & Exporter & Innovator \\
\hline Transportation (TR) & number & 126 & 18 & 53 \\
& in \% & 12.48 & 14.29 & 42.06 \\
\hline Information Technology (IT) & number & 82 & 28 & 55 \\
& in \% & 8.12 & 34.15 & 67.07 \\
\hline Technical Consultancy / & number & 179 & 48 & 100 \\
Engineering (TC) & in \% & 17.72 & 26.82 & 55.87 \\
\hline Housing Services (HO) & number & 99 & 2 & 30 \\
& in \% & 9.80 & 2.02 & 30.30 \\
\hline Consultancy / & number & 117 & 27 & 50 \\
Advertising (CO) & in \% & 11.58 & 23.08 & 42.74 \\
\hline Cleaning / & number & 119 & 4 & 57 \\
Waste Disposal (CL) & in \% & 11.78 & 3.36 & 47.90 \\
\hline Others Services (OT) & number & 288 & 64 & 144 \\
& in \% & 28.51 & 22.22 & 50.00 \\
\hline \hline Total & number & 1010 & 191 & 489 \\
& in \% & 100.00 & 18.91 & 48.42 \\
\hline
\end{tabular}


Table 2: Descriptive Statistics

\begin{tabular}{|c|c|c|c|c|c|}
\hline & \multicolumn{2}{|c|}{ Exporter } & \multicolumn{2}{|c|}{ Innovator } \\
\hline & & No & Yes & No & Yes \\
\hline \multicolumn{2}{|c|}{ Number of firms } & 819 & 191 & 521 & 489 \\
\hline Exporter & mean & & & 0.12 & 0.26 \\
\hline Innovator & mean & 0.44 & 0.67 & & \\
\hline \multicolumn{6}{|c|}{ Quantit. Variables: } \\
\hline \multirow[t]{2}{*}{ Inno } & mean & 0.03 & 0.07 & & \\
\hline & s.d. & 0.11 & 0.16 & & \\
\hline \multirow[t]{2}{*}{ Unit LC } & mean & 0.47 & 0.45 & 0.44 & 0.49 \\
\hline & s.d. & 0.33 & 0.54 & 0.35 & 0.40 \\
\hline \multirow[t]{2}{*}{ Wage ${ }^{\dagger}$} & mean & 0.67 & 0.92 & 0.69 & 0.74 \\
\hline & s.d. & 0.51 & 0.74 & 0.67 & 0.43 \\
\hline \multirow[t]{2}{*}{ Univ } & mean & 0.22 & 0.33 & 0.19 & 0.29 \\
\hline & s.d. & 0.29 & 0.32 & 0.28 & 0.31 \\
\hline \multirow[t]{2}{*}{ Skill } & mean & 0.52 & 0.50 & 0.55 & 0.49 \\
\hline & s.d. & 0.33 & 0.30 & 0.34 & 0.30 \\
\hline \multirow[t]{2}{*}{ Size } & mean & 0.15 & 0.16 & 0.09 & 0.22 \\
\hline & s.d. & 0.42 & 0.43 & 0.24 & 0.55 \\
\hline \multirow[t]{2}{*}{$\operatorname{InvI}$} & mean & 0.02 & 0.02 & 0.01 & 0.02 \\
\hline & s.d. & 0.04 & 0.03 & 0.03 & 0.05 \\
\hline \multicolumn{6}{|c|}{ Qualit. Variables: } \\
\hline Border & mean & 0.04 & 0.10 & 0.06 & 0.04 \\
\hline Cong & mean & 0.24 & 0.34 & 0.19 & 0.33 \\
\hline East & mean & 0.49 & 0.20 & 0.47 & 0.40 \\
\hline
\end{tabular}

$\dagger$ The variable $W_{a g e} e_{i j}$ was multiplied by factor 10 to ensure convergence in the iteration process of estimations. 
Table 3: Results of Probit Estimations

\begin{tabular}{|c|c|c|c|c|}
\hline \multirow[b]{3}{*}{ Variable } & \multicolumn{4}{|c|}{ Simple Probit Equation } \\
\hline & \multicolumn{2}{|c|}{ Version I } & \multicolumn{2}{|c|}{ Version II } \\
\hline & Coefficient & s.d. & Coefficient & s.d. \\
\hline Inno & $1.134^{* * *}$ & 0.375 & & \\
\hline Innovator & & & $0.462^{* * *}$ & 0.110 \\
\hline Quantitative $^{\dagger, \dagger \dagger}$ & & & & \\
\hline Unit $L C T R$ & $-2.072^{* *}$ & 0.912 & $-2.009^{* *}$ & 0.892 \\
\hline UnitLC_IT & 0.996 & 0.767 & $1.263^{*}$ & 0.750 \\
\hline Unit LC_TC & $-1.243^{* *}$ & 0.614 & $-1.308^{* *}$ & 0.621 \\
\hline Unit_LC_HO & -0.931 & 2.390 & -0.951 & 2.367 \\
\hline Unit_LC_CO & 0.082 & 0.183 & 0.053 & 0.185 \\
\hline Unit_LC_CL & -1.852 & 1.274 & -1.987 & 1.293 \\
\hline UnitLC_OT & $-1.135^{* * *}$ & 0.372 & $-1.167^{* * *}$ & 0.377 \\
\hline Wage & $0.288^{* * *}$ & 0.079 & $0.289^{* * *}$ & 0.078 \\
\hline Size & -0.089 & 0.107 & -0.117 & 0.108 \\
\hline Size2 & $-0.028^{*}$ & 0.018 & -0.027 & 0.018 \\
\hline \multicolumn{5}{|l|}{ Qualitative $^{\dagger \dagger, \dagger \dagger \dagger}$} \\
\hline Border & $0.447^{* *}$ & 0.201 & $0.505^{* *}$ & 0.201 \\
\hline Cong & 0.119 & 0.126 & 0.090 & 0.128 \\
\hline East & $-0.678^{* * *}$ & 0.120 & $-0.660^{* * *}$ & 0.120 \\
\hline$I D T R$ & $0.652^{*}$ & 0.394 & $0.637^{*}$ & 0.389 \\
\hline$I D \_I T$ & -0.226 & 0.426 & -0.374 & 0.425 \\
\hline$I D_{-} T C$ & $1.001^{* *}$ & 0.396 & $1.024^{*}$ & 0.399 \\
\hline$I D_{-} H O$ & $-1.059^{* *}$ & 0.498 & $-1.027^{* *}$ & 0.496 \\
\hline$I D \_C L$ & -0.367 & 0.544 & -0.295 & 0.544 \\
\hline$I D \_O T$ & $0.488^{* *}$ & 0.232 & $0.474^{* *}$ & 0.234 \\
\hline Constant & $-0.859^{* * *}$ & 0.252 & $-1.155^{* * *}$ & 0.269 \\
\hline Loglikelihood & -392.99 & & -388.33 & \\
\hline$n$ & 1010 & & 1010 & \\
\hline
\end{tabular}

Coefficients with significance to the level of $1 \%(5 \%, 10 \%)$ are marked with $* * *$ $(* *, *)$.

$\dagger$ The coefficients of $U n i t L C$ are allowed to vary across industries. ${ }^{\dagger \dagger} I D$ stands for industry dummy. ${ }^{\dagger \dagger}$ See table 1 for explanation of $T R, I T, T C, H O, C O, C L$ and $O T$. 
Table 4: Results of Simultaneous Probit Estimation

\begin{tabular}{|c|c|c|c|c|}
\hline \multirow[b]{3}{*}{ Variable } & \multicolumn{4}{|c|}{ Simultaneous Probit Equation } \\
\hline & \multicolumn{2}{|c|}{ Export Equation } & \multicolumn{2}{|c|}{ Innovation Equation } \\
\hline & Coefficient & s.d. & Coefficient & s.d. \\
\hline $\operatorname{Exp}$ & & & 0.115 & 0.111 \\
\hline Inno & $0.282^{* *}$ & 0.147 & & \\
\hline Quantitative ${ }^{\dagger, \dagger \dagger}$ & & & & \\
\hline UnitLCTR & $-1.997^{* *}$ & 0.876 & & \\
\hline Unit LC_IT & $1.291^{*}$ & 0.760 & & \\
\hline Unit LCTC & $-1.242^{* *}$ & 0.584 & & \\
\hline Unit_LC_HO & -0.904 & 2.443 & & \\
\hline Unit_LC_CO & 0.029 & 0.167 & & \\
\hline Unit_LC_CL & -1.754 & 1.212 & & \\
\hline Unit $L C \_O T$ & $-1.094^{* * *}$ & 0.366 & & \\
\hline Wage & $0.279^{* * *}$ & 0.085 & -0.082 & 0.079 \\
\hline Univ & & & $1.176^{* * *}$ & 0.237 \\
\hline Skill & & & $0.398^{* *}$ & 0.172 \\
\hline Size & -0.150 & 0.111 & $0.246^{* * *}$ & 0.093 \\
\hline Sized & -0.027 & 0.018 & -0.003 & 0.015 \\
\hline $\operatorname{InvI}$ & & & $4.780^{* * *}$ & 1.486 \\
\hline Qualitative ${ }^{\dagger \dagger, \dagger \dagger \dagger}$ & & & & \\
\hline Border & $0.506^{* *}$ & 0.219 & & \\
\hline Cong & 0.063 & 0.130 & 0.115 & 0.108 \\
\hline East & $-0.643^{* * *}$ & 0.119 & -0.091 & 0.130 \\
\hline$I D \_T R$ & 0.614 & 0.389 & $0.339^{*}$ & 0.187 \\
\hline$I D \_I T$ & -0.500 & 0.441 & $0.503^{* *}$ & 0.197 \\
\hline$I D-T C$ & $0.924^{* *}$ & 0.379 & 0.138 & 0.166 \\
\hline$I D \_H O$ & $-1.012^{* *}$ & 0.507 & -0.019 & 0.246 \\
\hline$I D \_C O$ & -0.398 & 0.537 & $0.468^{* *}$ & 0.232 \\
\hline$I D \_C L$ & $0.425^{*}$ & 0.230 & $0.316^{* *}$ & 0.153 \\
\hline Constant & $-0.977^{* * *}$ & 0.263 & 0.186 & 0.265 \\
\hline Loglikelihood & -395.25 & & -615.4 & \\
\hline$n$ & 1010 & & 1010 & \\
\hline
\end{tabular}

Coefficients with significance to the level of $1 \%(5 \%, 10 \%)$ are marked with *** $(* *, *)$.

$\dagger$ The coefficients of $U n i t L C$ are allowed to vary across industries. ${ }^{\dagger} I D$ stands for industry dummy. ${ }^{\dagger \dagger}$ See table 1 for explanation of $T R, I T, T C, H O, C O, C L$ and $O T$. 
Table 5: Results of Wald Tests

\begin{tabular}{|l|c|c|}
\hline $\begin{array}{l}\text { Wald Tests in the } \\
\text { Simple Probit Model }\end{array}$ & $\begin{array}{c}\text { Equation } 1 \\
\chi^{2} \text {-statistic }\end{array}$ & $\begin{array}{c}\text { Equation } 2 \\
\chi^{2} \text {-statistic }\end{array}$ \\
\hline \hline $\begin{array}{l}\text { - joint significance of coefficients } \\
\text { of } U \text { nit_LC variables }\end{array}$ & $\mathrm{W}(7)=22,18^{* * *}$ & $\mathrm{~W}(7)=23,90^{* * *}$ \\
\hline $\begin{array}{l}\text { - equality of coefficients } \\
\text { of } U \text { nit } L C \text { variables }\end{array}$ & $\mathrm{W}(6)=19,53^{* * *}$ & $\mathrm{~W}(6)=20,97^{* * *}$ \\
\hline $\begin{array}{l}\text { - joint significance of coeffients } \\
\text { of } S i z e \text { variables }\end{array}$ & $\mathrm{W}(2)=5,97^{*}$ & $\mathrm{~W}(2)=3,20$ \\
\hline $\begin{array}{l}\text { - joint significance of coeffients } \\
\text { of } I D \text { variables }\end{array}$ & $\mathrm{W}(6)=20,69^{* * *}$ & $\mathrm{~W}(6)=20,93^{* * *}$ \\
\hline
\end{tabular}

\begin{tabular}{|l|c|c|}
\hline $\begin{array}{l}\text { Wald Tests in the } \\
\text { Simultaneous Probit Model }\end{array}$ & $\begin{array}{c}\text { Export eq. } \\
\chi^{2} \text {-statistic }\end{array}$ & $\begin{array}{c}\text { Innovation eq. } \\
\chi^{2} \text {-statistic }\end{array}$ \\
\hline \hline $\begin{array}{l}\text { - joint significance of coeffients } \\
\text { of } U n i t L C \text { variables }\end{array}$ & $\mathrm{W}(7)=23,03^{* * *}$ & \\
\hline $\begin{array}{l}\text { - equality of coefficients } \\
\text { of } U n i t \_L C \text { variables }\end{array}$ & $\mathrm{W}(6)=36,88^{* * *}$ & \\
\hline $\begin{array}{l}\text { - joint significance of coefficients } \\
\text { of } S i z e \text { variables }\end{array}$ & $\mathrm{W}(2)=2,38$ & $\mathrm{~W}(2)=66,51^{* * *}$ \\
\hline $\begin{array}{l}\text { - joint significance of coefficients } \\
\text { of } I D \text { variables }\end{array}$ & $\mathrm{W}(6)=20,31^{* * *}$ & $\mathrm{~W}(6)=13,79^{* *}$ \\
\hline
\end{tabular}

Tests with size of $1 \%(5 \%, 10 \%)$ are marked with $* * *(* *, *)$. 